\title{
Synthesis of Novel Heterocyclic Imine Type UV Absorbers for Application on Cotton Based Textile Materials
}

\author{
Nuket Ocal, ${ }^{1}$ Acelya Aker, ${ }^{1}$ Hikmet Nil Ergindemir, ${ }^{2}$ and Agamirze Hamitbeyli ${ }^{2}$ \\ ${ }^{1}$ Yildiz Technical University, Faculty of Art and Sciences, Department of Chemistry, Davutpasa Campus, \\ 34220 Esenler-Istanbul, Turkey \\ ${ }^{2}$ Sanko Holding, ISKO Division, Organize Sanayi Bölgesi, 3. Cadde, İnegöl-Bursa, Turkey \\ Correspondence should be addressed to Nuket Ocal; nocal@yildiz.edu.tr
}

Received 29 September 2016; Accepted 15 November 2016

Academic Editor: Artur M. S. Silva

Copyright (C) 2016 Nuket Ocal et al. This is an open access article distributed under the Creative Commons Attribution License, which permits unrestricted use, distribution, and reproduction in any medium, provided the original work is properly cited.

\begin{abstract}
Novel Schiff bases with the potential to exhibit biologically active and UV absorption properties were synthesized. Their application on cotton based textile materials was performed and the UV protection factor (UPF) values and the antibacterial features of the treated fabrics were measured.
\end{abstract}

\section{Introduction}

Heterocyclic compounds are found in many natural and synthetic products with a wide range of pharmacological activities, such as antiviral, anticancer, antibacterial, antifungal, anticonvulsant, antiparkinsonian, and anti-inflammatory, that can be well illustrated by the large number of drugs in the market containing these functional groups. In recent years, many heterocyclic compounds have been synthesized and their biological activities researched. In particular the behavior of heterocyclic compounds against cancer cells has been investigated $[1,2]$. At the beginning of the 20th century, five-membered heterocyclic compounds such pyrrole, imidazole, thiazole, oxazole, pyrazole, indole, and thiazolidinones have attracted great interest among pharmaceutical chemists, because of their usage as raw materials for drugs [3-5]. As a result of over 100 years of investigation on heterocyclic compounds, it is clear that the usage of nitrogen, oxygen, and sulfur containing structures in bioactive compounds allows for tremendous variability. On the other hand, these types of compounds are gaining in importance owing to their UV absorption characteristics [6-8]. Sunlight includes significant UV radiation, which can be destructive to human health. It is known that long term exposure to UV radiation causes harmful effects on the human skin, some of which are sunburn, erythema, skin ageing, and, most importantly, the risk of skin cancer. In this case, the use of protective textile garments becomes a focus of great interest. UV radiation also causes unfavorable effects on synthetic materials. For greater protection from this exposure, the use of UV absorbing materials in textiles is needed.

Imines, also known as azomethines or Schiff bases, are condensation products of primary amines with carbonyl compounds. Imines also have a wide range of biological activities, including antifungal, antibacterial, anti-inflammatory, and antiviral activities [9-11]. Schiff bases are used in industrial applications such as photostabilization of poly(vinyl chloride) [12,13], poly(methyl methacrylate) [12], and polystyrene from photodegradation by their addition to polymer films [14].

The most common method for Schiff base synthesis is the reaction of an aldehyde or a ketone with a primary amine with elimination of a water molecule. This reaction is mostly accomplished by acid catalysis to obtain the products in good yields. For removal of water, several dehydrating agents have been used such as sodium sulfate. In addition, alternative methods, including tetramethyl orthosilicate or trimethyl orthoformate, have been reported [15-17]. As catalysts, mineral acids, organic acids, and Lewis acids have been reported [18-21]. Several synthesis techniques for Schiff bases have been reported, including solvent-free methods, microwave, 

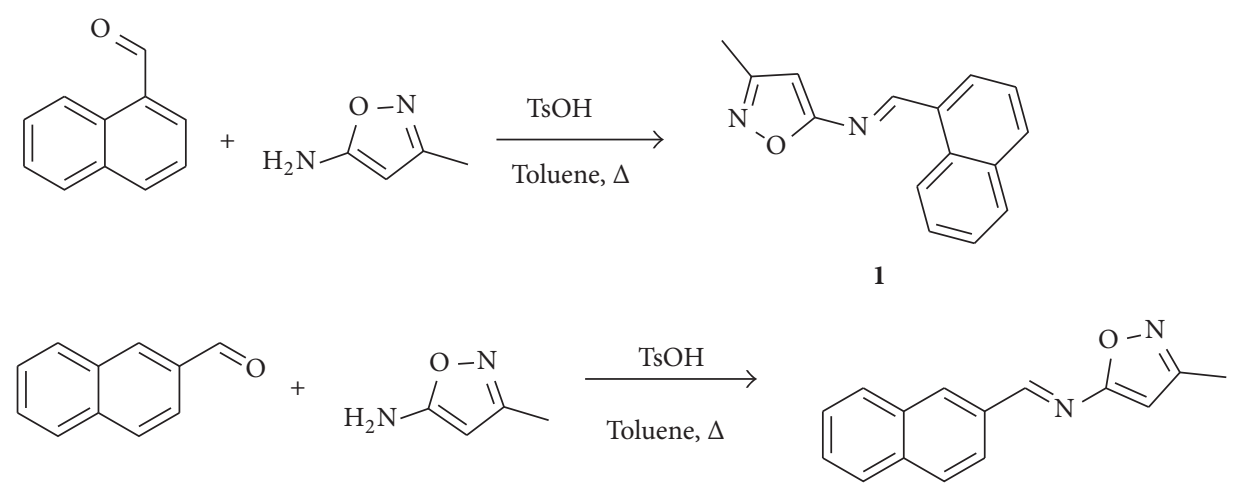

2<smiles>Cc1cc(/C=N/c2ccc3ccc4cccc5ccc2c3c45)on1</smiles>

3
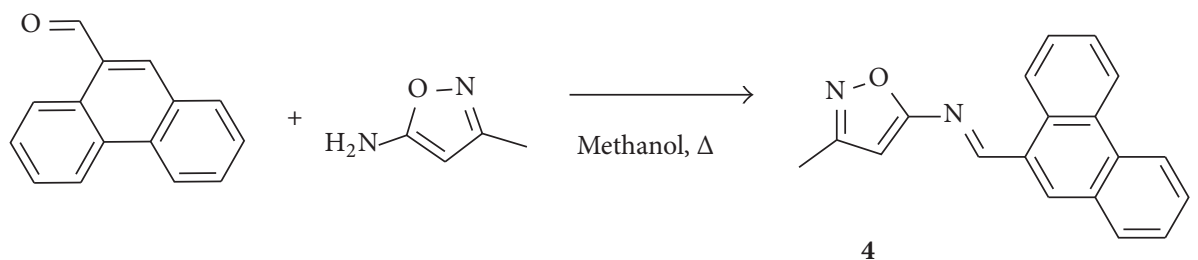

FIGURE 1: Synthesis of compounds 1-4.

and ultrasound methods as well as the use of water suspension medium, liquid crystals, and molecular sieves [22-32].

We recently prepared several new bis(indolyl)methanes and their UV absorbing behaviors were investigated both in solution and in polymer substrates [33]. After successful results, several new Schiff bases (aldimines) were prepared by condensation of 5-amino-3-methylisoxazole which was chosen similarity of active group of epiboxidine which are reported as potent nicotinic receptor [34] with aryl aldehydes as described in Section 3 and their UV absorbing behaviors were investigated. Imine compounds which were prepared easily in good yields have been selected due to conjugation to improve UPF values of cotton fabric.

\section{Results and Discussion}

2.1. Synthesis. Condensation of 5-amino-3-methylisoxazole with 1-naphthaldehyde, 2-naphthaldehyde, 1-pyrenecarbaldehyde, and phenanthrene-9-carbaldehyde in the presence of p-toluenesulfonic acid ( $\mathrm{TsOH}$; except 4) gave aldimine compounds 1-4 (Figure 1).

The structures of new aldimines were firmly established on the basis of IR, NMR, and mass spectra which were in agreement with the proposed structures. Introduction of aryl aldehydes onto isoxazole ring chromophore improved their UV absorbances (Table 1). From their UV spectra it is easy to
TABle 1: Properties of new compounds.

\begin{tabular}{lcccc}
\hline Product & $\begin{array}{c}\text { Time } \\
(\mathrm{min})\end{array}$ & $\begin{array}{c}\text { Yield } \\
(\%)\end{array}$ & $\mathrm{Mp}\left({ }^{\circ} \mathrm{C}\right)$ & $\begin{array}{c}\lambda_{\max } / \mathrm{nm} \\
(\text { absorbance })\end{array}$ \\
\hline $\mathbf{1}$ & 240 & 54 & $90-92$ & $350(0.87)$ \\
$\mathbf{2}$ & 240 & 58 & $195-197$ & $385(0.80)$ \\
$\mathbf{3}$ & 2 & 36 & $159-162$ & $425(1.10)$ \\
$\mathbf{4}$ & 1200 & 42 & $170-171$ & $360(1.20)$ \\
\hline
\end{tabular}

see why compounds 1-4 are excellent UV absorber chromophores. Figure 2 shows the UV spectra of compounds 1 and 4, respectively. The ${ }^{1} \mathrm{H}$ NMR spectra of $\mathbf{1 - 4}$ displayed singlets at 9.80-9.42 ppm due to the imine protons in addition to other signals. In the IR spectra of the compounds, carbonyl bands were absent which clearly confirmed that a condensation with the aryl aldehydes had taken place.

2.2. Textile Applications. For textile applications, compounds 1-4 were dissolved in dichloromethane, mixed with printing paste, and applied on $100 \%$ cotton undyed fabrics. The raw and all printed fabrics were subjected to AATCC 183:2014 (The American Association of Textile Chemists and Colorists. Transmittance or Blocking of Erythemally Weighted Ultraviolet Radiation through Fabrics; AATCC: Research Triangle 

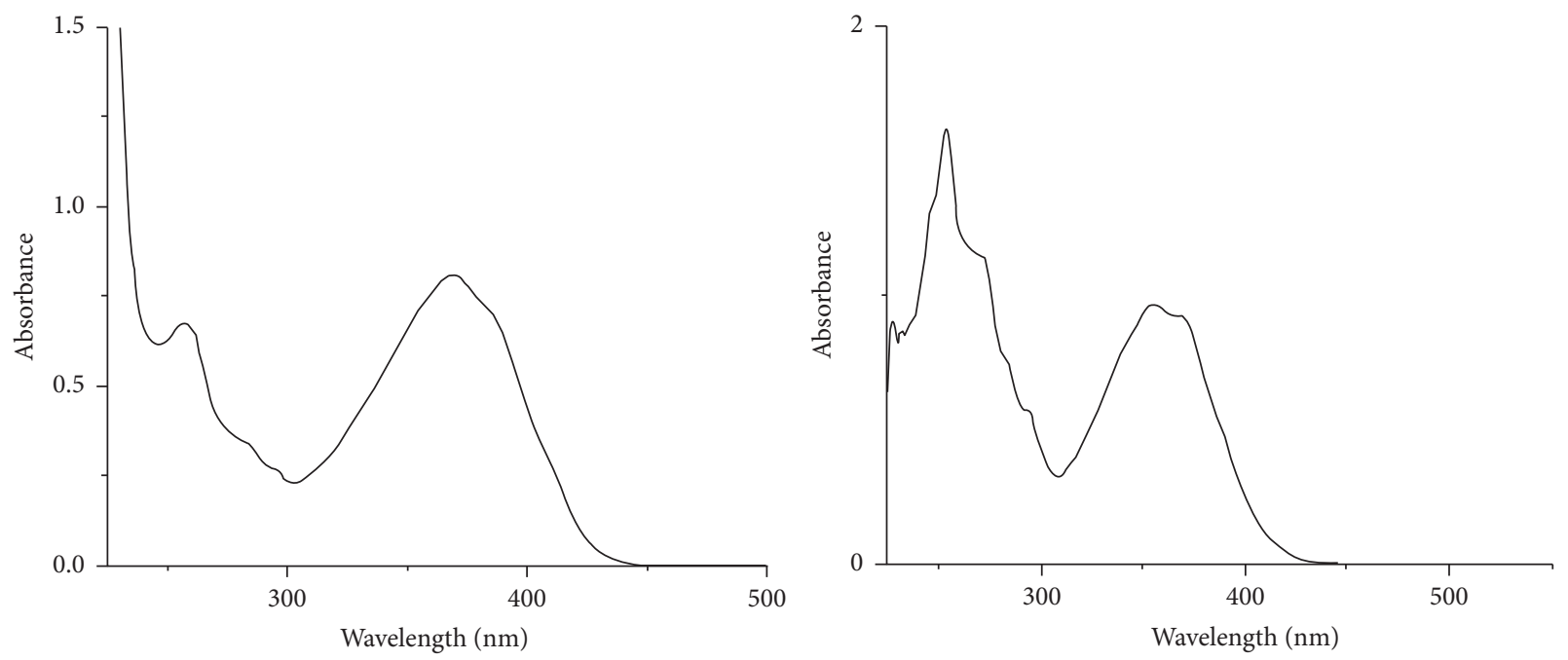

FIgURE 2: UV spectra of compounds 1 and $\mathbf{4}$, respectively.

TABLE 2: UV protective features of absorbers.

\begin{tabular}{|c|c|c|c|c|c|c|}
\hline $\begin{array}{l}\text { UV absorber printed } \\
\text { fabric }\end{array}$ & $\begin{array}{c}\text { UVA } \\
\text { transmittance* } \\
(315-400 \mathrm{~nm})\end{array}$ & $\begin{array}{c}\text { UVB } \\
\text { transmittance* } \\
(280-315 \mathrm{~nm}) \\
\end{array}$ & UPF & $\begin{array}{c}\text { UVA } \\
\text { blocking (\%) }\end{array}$ & $\begin{array}{c}\text { UVB } \\
\text { blocking (\%) }\end{array}$ & $\begin{array}{l}\text { UPF } \\
\text { label }\end{array}$ \\
\hline Reference & 5.65 & 2.02 & 33.37 & 94.35 & 97.98 & 27 \\
\hline 1 & 0.27 & 0.05 & 1709.2 & 99.73 & 99.50 & $40+$ \\
\hline 2 & 2.72 & 0.15 & 223.52 & 97.28 & 99.85 & $40+$ \\
\hline 3 & 0.27 & 0.13 & 531.89 & 99.73 & 99.87 & $50+$ \\
\hline 4 & 2.93 & 0.05 & 307.60 & 97.07 & 99.95 & $50+$ \\
\hline
\end{tabular}

*Average.

Park, NC, USA, 2014) standard tests at $21^{\circ} \mathrm{C}$ temperature and $66 \%$ relative humidity.

These results show that the UPF: 27 value of standard fabric increases up to $40+$ and $50+$ upon Schiff base treatments. According to standard specimens, a UPF value of $15-24$ is good, 25-39 is very good, and 40 or greater is excellent UVprotection category. That means both UVA and UVB transmission through fabrics decreased and excellent protection obtained (Table 2). All printed fabrics were washed 25 times according to BS EN ISO 6330 5A standard (Domestic washing and drying procedures for textile testing. Available online: https://www.iso.org/obp/ui/\#iso:std:43044:en (accessed on 15 March 2012)), 6330 5A standard [26]. The UPF values were also tested after 25 washing cycles. The UPF values are the same as the unwashed fabrics, at $40+$. In accordance with this, we still have the protective property after multiple washing cycles. After connecting to the fabric of the imine compounds have been shown to be binding strongly.

Antibacterial activities were tested according to AATCC147-2011 standard (available online: https://www.oeko-tex.com/en/manufacturers/manufacturers.xhtml, (accessed on 5 February 2016)), at $37 \pm 2^{\circ} \mathrm{C}$ temperature and $18-24 \mathrm{~h}$ incubation time for Staphylococcus aureus (AATCC 6538 Gram+) microorganism (Antibacterial Activity Assessment
TABLE 3: Antibacterial features of absorbers.

\begin{tabular}{lccc}
\hline $\begin{array}{l}\text { Fabric } \\
\text { printed }\end{array}$ & Washes & $\begin{array}{c}\text { Bacteria } \\
\text { growth }\end{array}$ & $\begin{array}{c}\text { Inhibition } \\
\text { zone }(\mathrm{mm})^{*}\end{array}$ \\
\hline reference & - & + & \\
$\mathbf{1}$ & 25 & - & 0 \\
2 & 25 & - & 0 \\
3 & 25 & - & 0 \\
$\mathbf{4}$ & 25 & - & 0 \\
\hline
\end{tabular}

${ }^{*}$ Width of clear zone of inhibition (positive = there is bacterial growth; negative $=$ there is not bacterial growth).

of Textile Materials). The results show the antibacterial activities achieved (Table 3). Furthermore, we tested the coated fabrics and compared them to the OEKO TEX 100 standard for PAH (polyaromatic hydrocarbon), APEO (alkylphenyl ethylate), and phthalate contents. According to the results, it can be said that the fabrics do not have toxic properties.

\section{Experimental}

3.1. General Information. Reactions were monitored using thin-layer chromatography (TLC). The crude products were 
purified by silica gel chromatography with a solvent mixture to afford the title compounds. UV absorption spectra were recorded on an Agilent Technologies 8453 spectrophotometer. IR spectra were obtained with a "Perkin Elmer, FT-IR" system and are reported in terms of frequency of absorption $\left(\mathrm{cm}^{-1}\right)$. Melting points were determined with a "Gallenkamp" digital thermometer. All melting points are uncorrected. NMR spectra were determined with a "Bruker Ac$500 \mathrm{MHz}$ NMR.” TMS (tetramethylsilane) was used as internal standard and $\mathrm{CDCl}_{3}$ was used as the solvent. Signal multiplicities in the NMR spectra are reported as follows: ssinglet, brs-broad singlet, d-doublet, dd-doublet of doublets, and m-multiplet. Mass spectra were measured with Agilent 6890N GC-System-5973 IMSD or Agilent LC-MSD Trap SL. All tests related to textile applications are done by 3 rd party laboratories having accreditation. Tests for transmittance or blocking of erythemally weighted ultraviolet radiation trough fabrics (AATCC 183:2014) tests were performed at Intertek laboratories, Istanbul, Turkey. Domestic washing and drying procedures for textile (BS EN ISO 6330 5A) tests were made in Sanko holding-ISKO division R\&D laboratories Bursa/ Turkey. Antibacterial activity assessment of textile materials (AATCC147-2011) tests were performed at Ekoteks laboratories, Istanbul, Turkey.

\subsection{Synthesis of $\mathbf{1}-\mathbf{4}$}

N-(3-Methylisoxazol-5-yl)-1-(naphthalen-1-yl)methanimine (1). 5-Amino-3-methylisoxazole ( $3 \mathrm{mmol}$ ) and 1-naphthaldehyde $(3 \mathrm{mmol})$ were dissolved in $12 \mathrm{~mL}$ of anhydrous toluene under nitrogen atmosphere. $p$-Toluenesulfonic acid $(\mathrm{TsOH})$ $(0.3 \mathrm{mmol})$ and molecular sieve $(3 \mathrm{~g}$, previously activated at $140^{\circ} \mathrm{C}$ for 4 days) were added and refluxed for $4 \mathrm{~h}$. The progress of the reaction was monitored by TLC. The residue was filtered, toluene was evaporated, and crude compound 1 was recrystallized from acetonitrile in an ultrasonic bath. Yellow crystals; mp: $90-92^{\circ} \mathrm{C}$, Yield $=58 \% ; R_{f}=0.28(1: 5$; EtOAc/ $n$-hexane); FTIR (ATR): $v=3050,2918,2849,1618$, $1595,1562,1442,1414,1337,1175,732,693 \mathrm{~cm}^{-1} ;{ }^{1} \mathrm{H} \mathrm{NMR}$ $\left(\mathrm{CDCl}_{3}, 500 \mathrm{MHz}\right): \delta=1.88\left(\mathrm{~s}, 3 \mathrm{H}, \mathrm{CH}_{3}\right), 6.38(\mathrm{~s}, 1 \mathrm{H},=\mathrm{CH})$, 7.34-7.51 (m, 4H, ArH), 7.81 (d, J = 8.51 Hz, 1H, ArH), 7.92 $(\mathrm{dd}, J=8.19 ; 11.65 \mathrm{~Hz}, 1 \mathrm{H}, \mathrm{ArH}), 8.66(\mathrm{~d}, J=8.51 \mathrm{~Hz}, 1 \mathrm{H}$, $\mathrm{ArH}), 9.45$ (s, 1H, =CH) ppm; ${ }^{13} \mathrm{C} \mathrm{NMR}\left(\mathrm{CDCl}_{3}, 125 \mathrm{MHz}\right)$ : $\delta=12.35\left(\mathrm{CH}_{3}\right), 111.19(\mathrm{CH}), 123.57(\mathrm{CH}), 125.28(\mathrm{CH})$, $126.34(\mathrm{CH}), 127.89(\mathrm{CH}), 128.82(\mathrm{CH}), 130.51(\mathrm{CH}), 130.87$ $(\mathrm{CH}), 131.70(\mathrm{Cq}), 133.42(\mathrm{Cq}), 133.62(\mathrm{Cq}), 161.21(\mathrm{Cq}), 162.23$ (Cq) ppm; UV $\left(\lambda_{\max }, \mathrm{CH}_{2} \mathrm{Cl}_{2}\right): 385 \mathrm{~nm}\left(c=1.5 \times 10^{-4}\right.$, $\left.A=0.80, \varepsilon=5.4 \times 10^{3}\right)$; LC-MS (ESI): $m / z=236\left(\mathrm{M}^{+}\right)$for $\mathrm{C}_{15} \mathrm{H}_{12} \mathrm{~N}_{2} \mathrm{O}$.

N-(3-Methylisoxazol-5-yl)-1-(naphthalen-2-yl)methanimine (2). 5-Amino-3-methylisoxazole (5 mmol) and 2-naphthaldehyde $(5 \mathrm{mmol})$ were dissolved in $20 \mathrm{~mL}$ anhydrous toluene under nitrogen atmosphere. $p$-Toluenesulfonic acid $(\mathrm{TsOH})$ $(0.3 \mathrm{mmol})$ and molecular sieve $(3 \mathrm{~g}$, previously activated at $140^{\circ} \mathrm{C}$ for 4 days) were added and refluxed for $4 \mathrm{~h}$. The progress of the reaction was monitored by TLC. The residue was filtered, toluene was evaporated, and crude product 2 was recrystallized from methanol in an ultrasonic bath. Yellow crystals; mp: $195-197^{\circ} \mathrm{C}$, Yield $=54 \% ; R_{f}=0.31$ (1: 5; EtOAc/ $n$-hexane); FTIR (ATR): $v=3055,2927,2890,1595,1576$, $1438,1411,1373,1176,753,693 \mathrm{~cm}^{-1} ;{ }^{1} \mathrm{H} \mathrm{NMR}\left(\mathrm{CDCl}_{3}\right.$, $500 \mathrm{MHz}): \delta=2.34\left(\mathrm{~s}, 3 \mathrm{H}, \mathrm{CH}_{3}\right), 6.01(\mathrm{~s}, 1 \mathrm{H},=\mathrm{CH}), 7.54-7.61$ (m, 2H, ArH), 7.88-7.96 (m, 3H, ArH), 8.14 (d, $J=9.77 \mathrm{~Hz}$, $1 \mathrm{H}, \operatorname{ArH}), 8.26$ (s, 1H, ArH), $8.99(\mathrm{~s}, 1 \mathrm{H},=\mathrm{CH}) \mathrm{ppm} ;{ }^{13} \mathrm{C}$ $\operatorname{NMR}\left(\mathrm{CDCl}_{3}, 125 \mathrm{MHz}\right): \delta=12.33\left(\mathrm{CH}_{3}\right), 96.66(\mathrm{CH})$, $123.68(\mathrm{CH}), 126.97(\mathrm{CH}), 127.93(\mathrm{CH}), 128.44(\mathrm{CH}), 128.87$ $(\mathrm{CH}), 129.03(\mathrm{CH}), 132.97(\mathrm{Cq}), 133.36(\mathrm{Cq}), 135.70(\mathrm{Cq})$, $138.17(\mathrm{Cq}), 161.66(\mathrm{Cq}), 163.42(\mathrm{CH}) \mathrm{ppm}$; UV $\left(\lambda_{\max }\right.$, $\left.\mathrm{CH}_{2} \mathrm{Cl}_{2}\right): 350 \mathrm{~nm}\left(c=1.7 \times 10^{-7}, A=0.875, \varepsilon=5.16 \times 10^{6}\right)$; GC-MS (EI, $70 \mathrm{eV}): m / z=236\left(\mathrm{M}^{+}\right)$for $\mathrm{C}_{15} \mathrm{H}_{12} \mathrm{~N}_{2} \mathrm{O}$.

N-(3-Methylisoxazol-5-yl)-1-(phenanthen-9-yl)methanimine (3). 5-Amino-3-methylisoxazole ( $1 \mathrm{mmol})$, $p$-toluenesulfonic acid $(\mathrm{TsOH})(5 \mathrm{mg})$, and 1-pyrenecarbaldehyde (1 mmol) were dissolved in minimum amount of absolute ethanol in an ultrasonic bath. Silica gel (40 mg) was added to the mixture and the reaction was sonicated at $360 \mathrm{~W}$. The reaction was completed in $2 \mathrm{~min}$. The progress of the reaction was monitored by TLC. The residue was filtered and the crude product 3 was purified by column chromatography (1:5; EtOAc/nhexane). Yellow crystals; mp: $159-162^{\circ} \mathrm{C}$, Yield $=36 \% ; R_{f}=$ 0.30 (1:5; EtOAc/ $n$-hexane); FTIR (ATR): $v=3040,2921$, 2851, 1584, 1568, 1505, 1441, 1408, 1322, 1186, 717, $694 \mathrm{~cm}^{-1}$; ${ }^{1} \mathrm{H}$ NMR $\left(\mathrm{CDCl}_{3}, 500 \mathrm{MHz}\right): \delta=2.31\left(\mathrm{~s}, 3 \mathrm{H}, \mathrm{CH}_{3}\right), 6.11$ (s, $1 \mathrm{H},=\mathrm{CH}), 8.01(\mathrm{dd}, J=7.56 ; 9.77 \mathrm{~Hz}, 2 \mathrm{H}, \mathrm{ArH}), 8.13$ (dd, $J=8.19 ; 12.29 \mathrm{~Hz}, 2 \mathrm{H}, \mathrm{ArH}), 8.19-8.22(\mathrm{~m}, 3 \mathrm{H}, \mathrm{ArH})$, $8.70(\mathrm{~d}, J=8.19 \mathrm{~Hz}, 1 \mathrm{H}, \operatorname{ArH}), 8.88(\mathrm{~d}, J=9.77 \mathrm{~Hz}, 1 \mathrm{H}$, $\mathrm{ArH}), 9.80$ (s, 1H, =CH) ppm; ${ }^{13} \mathrm{C} \mathrm{NMR}\left(\mathrm{CDCl}_{3}, 125 \mathrm{MHz}\right)$ : $\delta=12.12\left(\mathrm{CH}_{3}\right), 96.84(\mathrm{Cq}), 97.28(\mathrm{CAr}), 98.32(\mathrm{Cq}), 122.01$ (CAr), $124.44(\mathrm{Cq}), 124.89$ (Cq), 126.40 (CAr), 126.61 (CAr), 126.82 (CAr), 126.96 (CAr), 127.37 (CAr), 129.77 (CAr), 129.87 (CAr), 130.05 (CAr), 130.48 (Cq), 131.18 (Cq), 131.79 (Cq), $134.71(\mathrm{Cq}), 161.40(\mathrm{CH}), 161.89(\mathrm{Cq}) \mathrm{ppm} ;\left(\lambda_{\max }, \mathrm{CH}_{2} \mathrm{Cl}_{2}\right)$ : $425 \mathrm{~nm}\left(c=7.78 \times 10^{-6}, A=1.1, \varepsilon=1.8 \times 10^{4}\right)$; LC-MS(ESI): $m / z=236\left(\mathrm{M}^{+}\right)$for $\mathrm{C}_{21} \mathrm{H}_{14} \mathrm{~N}_{2} \mathrm{O}$.

N-(3-Methylisoxazol-5-yl)-1-(pyren-1-yl)methanimine (4). 5Amino-3-methylisoxazole ( $1 \mathrm{mmol}$ ) was dissolved in $2 \mathrm{~mL}$ of absolute methanol at room temperature. Phenanthrene-9carbaldehyde $(1 \mathrm{mmol})$ and molecular sieve were added and the mixture was refluxed for $20 \mathrm{~h}$. The progress of the reaction was monitored by TLC. Compound 4 was purified by column chromatography (1:5; EtOAc/n-hexane). Yellow crystals; mp: $170-171^{\circ} \mathrm{C}$, Yield $=52 \% ; R_{f}=0.28$ (1:5; EtOAc/ $n$-hexane); FTIR (ATR): $v=3051,2917,1600,1564,1526,1489,1438$, $1409,1369,1194,745,711 \mathrm{~cm}^{-1} ;{ }^{1} \mathrm{H}$ NMR $\left(\mathrm{CDCl}_{3}, 500 \mathrm{MHz}\right)$ : $\delta=2.30\left(\mathrm{~s}, 3 \mathrm{H}, \mathrm{CH}_{3}\right), 6.09(\mathrm{~s}, 1 \mathrm{H},=\mathrm{CH}), 7.57-7.60(\mathrm{~m}, 1 \mathrm{H}$, ArH), 7.67-7.72 (m, 3H, ArH), 7.95 (d, J = 7.88 Hz, 1H, ArH), 8.37 (s, 1H, ArH), 8.63 (d, $J=8.19 \mathrm{~Hz}, 1 \mathrm{H}, \mathrm{ArH}), 8.69-8.71$ (m, 1H, ArH), 9.09-9.11 (m, 1H, ArH), 9.42 (s, 1H, =CH) ppm; ${ }^{13} \mathrm{C} \mathrm{NMR}\left(\mathrm{CDCl}_{3}, 125 \mathrm{MHz}\right): \delta=12.20\left(\mathrm{CH}_{3}\right), 97.36$ (CAr), 122.80 (CAr), 123.19 (CAr), 125.17 (CAr), 127.26 (CAr), 127.29 (CAr), 127.70 (CAr), 129.33 (CAr), 130.25 (Cq), 130.64 (Cq), 134.79 (CAr), $163.55(\mathrm{CH}) \mathrm{ppm} ;\left(\lambda_{\max }, \mathrm{CH}_{2} \mathrm{Cl}_{2}\right): 360 \mathrm{~nm}(c=$ $\left.1.48 \times 10^{-5}, A=1.20, \varepsilon=8.1 \times 10^{4}\right)$; GC-MS (EI, $\left.70 \mathrm{eV}\right)$ : $m / z=286\left(\mathrm{M}^{+}\right)$for $\mathrm{C}_{19} \mathrm{H}_{14} \mathrm{~N}_{2} \mathrm{O}$. 


\section{Conclusions}

In conclusion, we have prepared a new series of aryl aldimines which can be used as UV absorbers in the textile industry. They increased the UV protection factor of undyed fabric up to $40+$ and $50+$ from 27 . This shows that they are quite active as UV absorbers. Furthermore, all printed fabrics were washed 25 times according to standard procedure with minimal loss of UV protection. Tests results also indicated that the imine compounds exhibit antibacterial properties.

\section{Competing Interests}

The authors declare that they have no competing interests.

\section{Acknowledgments}

The authors gratefully acknowledge the financial support of this work by the Ministry of Science, Industry, and Technology (SANTEZ, Project no. 0048.STZ.2013-1) and SANKO Holding-ISKO Division.

\section{References}

[1] S. Kapitza, M. Pongratz, M. A. Jakupec et al., "Heterocyclic complexes of ruthenium(III) induce apoptosis in colorectal carcinoma cells," Journal of Cancer Research and Clinical Oncology, vol. 131, no. 2, pp. 101-110, 2005.

[2] H. Lage, E. Aki-Sener, and I. Yalcin, "High antineoplastic activity of new heterocyclic compounds in cancer cells with resistance against classical DNA topoisomerase II-targeting drugs," International Journal of Cancer, vol. 119, no. 1, pp. 213-220, 2006.

[3] L. Y. V. Mendez, V. Kouznetsov, J. C. Poveda, C. Yolacan, N. Ocal, and F. Aydogan, "Transformations of 4-N-Arylamino-4(8-quinolinyl)-1-butenes and 3-aryl-2-(8-quinolinyl)-4-thiazolidinones," Heterocyclic Communications, vol. 7, no. 2, pp. 129134, 2001.

[4] F. Aydogan, N. Öcal, Z. Turgut, and C. Yolacan, "Transformations of aldimines derived from pyrrole-2-carbaldehyde. Synthesis of thiazolidino-fused compounds," Bulletin of the Korean Chemical Society, vol. 22, no. 5, pp. 476-480, 2001.

[5] N. Öcal, F. Aydogan, Ç. Yolaçan, and Z. Turgut, "Synthesis of some furo-thiazolidine derivatives starting from aldimines," Journal of Heterocyclic Chemistry, vol. 40, no. 4, pp. 721-724, 2003.

[6] W. Czajkowski, J. Paluszkiewicz, R. Stolarski, M. Kaźmierska, and E. Grzesiak, "Synthesis of reactive UV absorbers, derivatives of monochlorotriazine, for improvement in protecting properties of cellulose fabrics," Dyes and Pigments, vol. 71, no. 3, pp. 224-230, 2006.

[7] J. Akrman and J. Přikryl, "Application of benzotriazole reactive UV absorbers to cellulose and determining sun protection of treated fabric spectrophotometrically," Journal of Applied Polymer Science, vol. 108, no. 1, pp. 334-341, 2008.

[8] S. Tragoonwichian, E. A. O’Rear, and N. Yanumet, "Broad ultraviolet protection by copolymerization of 2-[3- $(2 \mathrm{H}$-benzotriazol-2-yl)-4-hydroxyphenyl]ethyl methacrylate and 2-hydroxy-4-acryloyloxybenzophenone on cotton via admicellar polymerization," Journal of Applied Polymer Science, vol. 108, no. 6, pp. 4004-4013, 2008.
[9] S. Arulmurugan, P. H. Kavitha, and R. P. Venkatraman, "Biological activities of Schiff base and its complexes: a review," Rasayan Journal of Chemistry, vol. 3, no. 3, pp. 385-410, 2010.

[10] D. N. Dhar and C. L. Taploo, "Schiff bases and their applications," Journal of Scientific \& Industrial Research, vol. 41, no. 8, pp. 501-506, 1982.

[11] P. Przybylski, A. Huczynski, K. Pyta, B. Brzezinski, and F. Bartl, "Biological properties of schiff bases and azo derivatives of phenols," Current Organic Chemistry, vol. 13, no. 2, pp. 124-148, 2009.

[12] E. Yousif, N. Salih, and J. Salimon, "Improvement of the photostabilization of PVC films in the presence of $2 \mathrm{~N}$-salicylidene5-(substituted)-1,3, 4-thiadiazole," Journal of Applied Polymer Science, vol. 120, no. 4, pp. 2207-2214, 2011.

[13] M. W. Sabaa, E. H. Oraby, A. S. Abdel Naby, and R. R. Mohamed, " $N$-Phenyl-3-substituted 5-pyrazolone derivatives as organic stabilizers for rigid poly(vinyl chloride) against photodegradation," Journal of Applied Polymer Science, vol. 101, no. 3, pp. 15431555, 2006.

[14] E. Yousif, J. Salimon, and N. Salih, "New stabilizers for polystyrene based on 2- $N$-salicylidene-5-(substituted)-1,3,4-thiadiazole compounds," Journal of Saudi Chemical Society, vol. 16, no. 3, pp. 299-306, 2012.

[15] F. H. Westheimer and K. Taguchi, "Catalysis by molecular sieves in the preparation of ketimines and enamines," The Journal of Organic Chemistry, vol. 36, no. 11, pp. 1570-1572, 1971.

[16] B. E. Love and J. Ren, "Synthesis of sterically hindered imines," The Journal of Organic Chemistry, vol. 58, no. 20, pp. 5556-5557, 1993.

[17] G. C. Look, M. M. Murphy, D. A. Campbell, and M. A. Gallop, "Trimethylorthoformate: a mild and effective dehydrating reagent for solution and solid phase imine formation," Tetrahedron Letters, vol. 36, no. 17, pp. 2937-2940, 1995.

[18] R. H. Holm, J. G. W. Everett, and A. Chakravorty, "Metal complexes of Schiff bases and $\alpha$-aminoketones," Progress in Inorganic Chemistry, vol. 7, pp. 83-214, 1966.

[19] P. A. Vigato and S. Tamburini, "The challenge of cyclic and acyclic schiff bases and related derivatives," Coordination Chemistry Reviews, vol. 248, no. 17-20, pp. 1717-2128, 2004.

[20] R. W. Layer, “The chemistry of imines," Chemical Reviews, vol. 63, pp. 489-510, 1963.

[21] A. P. Dobbs and S. Rossiter, "Imines and their $N$-substituted derivatives: $\mathrm{NH}, \mathrm{NR}$, and $\mathrm{N}$-Haloimines," in Comprehensive Organic Functional Group Transformations II, R. K. Alan and R. J. K. Taylor, Eds., pp. 419-450, Elsevier, Oxford, UK, 2005.

[22] R. S. Varma, R. Dahiya, and S. Kumar, "Clay catalyzed synthesis of imines and enamines under solvent-free conditions using microwave irradiation," Tetrahedron Letters, vol. 38, no. 12, pp. 2039-2042, 1997.

[23] J. Schmeyers, F. Toda, J. Boy, and G. Kaupp, "Quantitative solidsolid synthesis of azomethines," Journal of Chemical Society, Perkin Transactions 2, vol. 4, pp. 989-994, 1998.

[24] A. Vass, J. Dudás, and R. S. Varma, "Solvent-free synthesis of $\mathrm{N}$-sulfonylimines using microwave irradiation," Tetrahedron Letters, vol. 40, no. 27, pp. 4951-4954, 1999.

[25] K. Tanaka and R. Shiraishi, "Clean and efficient condensation reactions of aldehydes and amines in a water suspension medium," Green Chemistry, vol. 2, no. 6, pp. 272-273, 2000.

[26] C. K. Z. Andrade, S. C. S. Takada, L. M. Alves et al., "Molecular sieves in ionic liquids as an efficient and recyclable medium for the synthesis of imines," Synlett, no. 12, pp. 2135-2138, 2004. 
[27] M. Á. Vázquez, M. Landa, L. Reyes, R. Miranda, J. Tamariz, and F. Delgado, "Infrared irradiation: effective promoter in the formation of $\mathrm{N}$-benzylideneanilines in the absence of solvent," Synthetic Communications, vol. 34, no. 15, pp. 2705-2718, 2004.

[28] M. Gopalakrishnan, P. Sureshkumar, V. Kanagarajan, and J. Thanusu, "New environmentally-friendly solvent-free synthesis of imines using calcium oxide under microwave irradiation," Research on Chemical Intermediates, vol. 33, no. 6, pp. 541-548, 2007.

[29] K. P. Guzen, A. S. Guarezemini, A. T. G. Órfão, R. Cella, C. M. P. Pereira, and H. A. Stefani, "Eco-friendly synthesis of imines by ultrasound irradiation," Tetrahedron Letters, vol. 48, no. 10, pp. 1845-1848, 2007.

[30] N. Öcal, C. Yolaçan, S. Kaban, V. M. Leonor, and V. Kouznetsov, "Transformations of schiff bases derived from quinoline-8carbaldehyde. Synthesis of C-8 substituted quinolines," Journal of Heterocyclic Chemistry, vol. 38, no. 1, pp. 233-236, 2001.

[31] N. Ocal, N. Mor, and I. Erden, "Substrate- and base-dependent reactivities of acylketene toward aryl aldimines derived from 2amino-4-methylpyridine," Tetrahedron Letters, vol. 56, no. 46, pp. 6468-6471, 2015.

[32] B. O. Sucu, N. Ocal, and I. Erden, "Direct synthesis of imidazolidin-4-ones via cycloadditions of imines with a Leuchs' anyhdride," Tetrahedron Letters, vol. 56, no. 20, pp. 2590-2592, 2015.

[33] H. N. Ergindemir, A. Aker, A. Hamitbeyli, and N. Ocal, "Synthesis of novel UV absorbers bisindolylmethanes and investigation of their applications on cotton-based textile materials," Molecules, vol. 21, no. 6, pp. 718-730, 2016.

[34] B. Badio, H. M. Garraffo, C. V. Plummer, W. L. Padgett, and J. W. Daly, "Synthesis and nicotinic activity of epiboxidine: an isoxazole analogue of epibatidine," European Journal of Pharmacology, vol. 321, no. 2, pp. 189-194, 1997. 

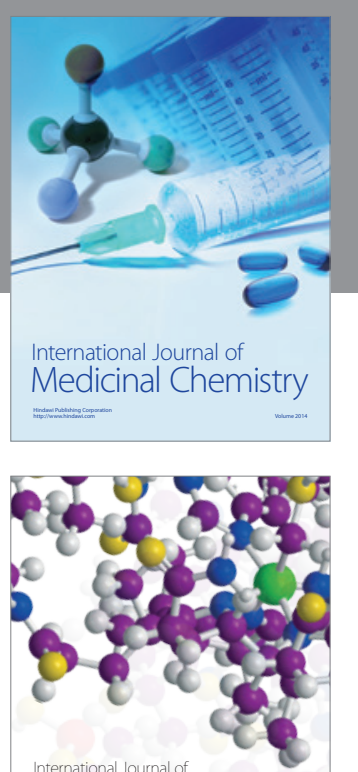

Carbohydrate Chemistry

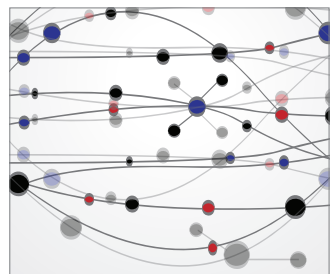

The Scientific World Journal
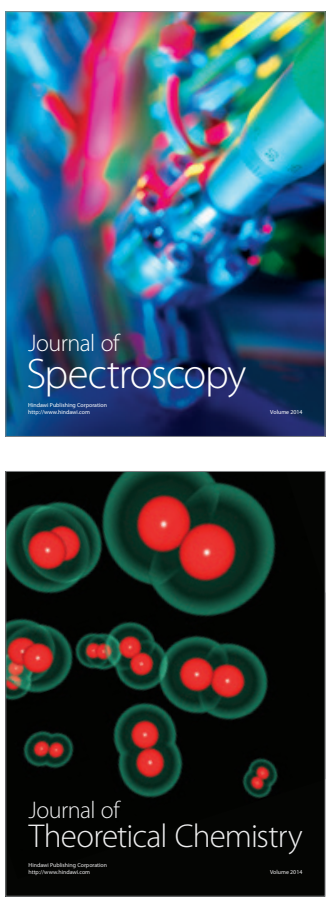
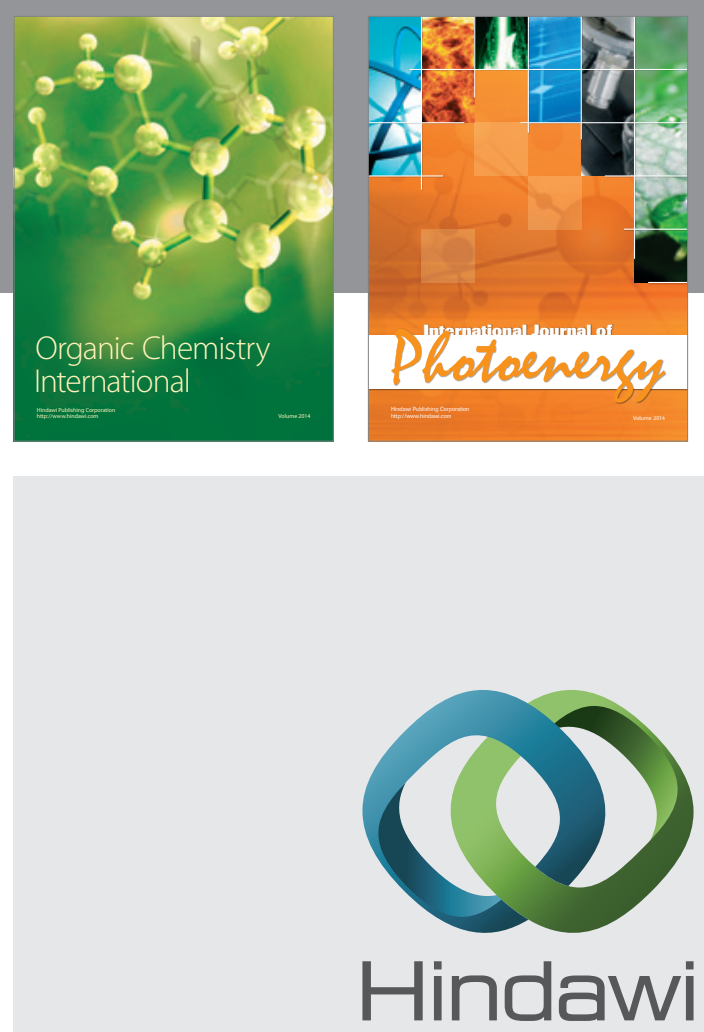

Submit your manuscripts at

http://www.hindawi.com

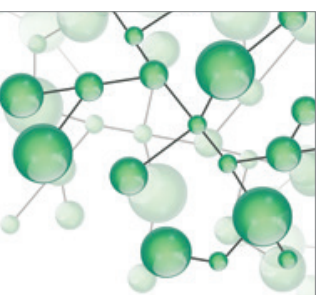

International Journal of

Inorganic Chemistry

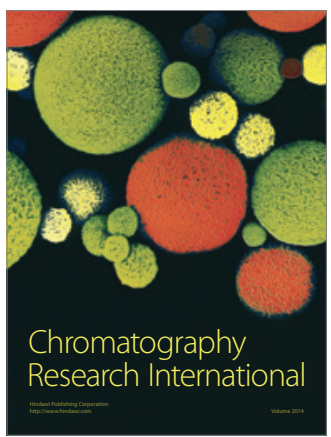

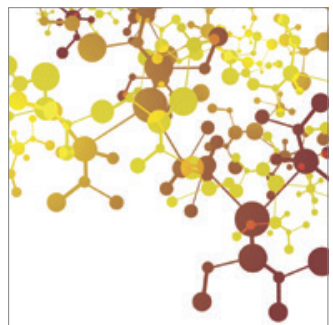

Applied Chemistry
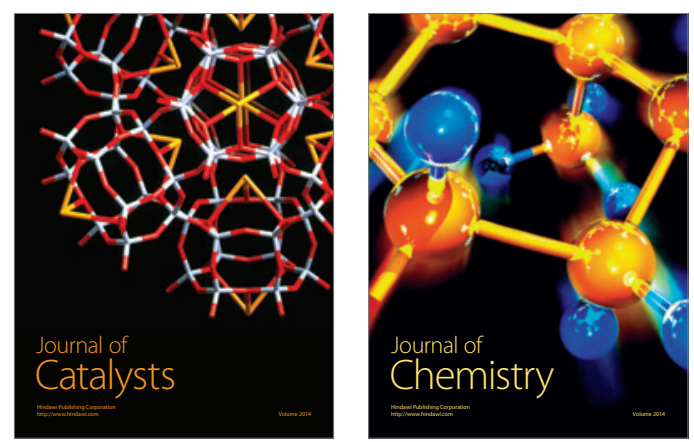
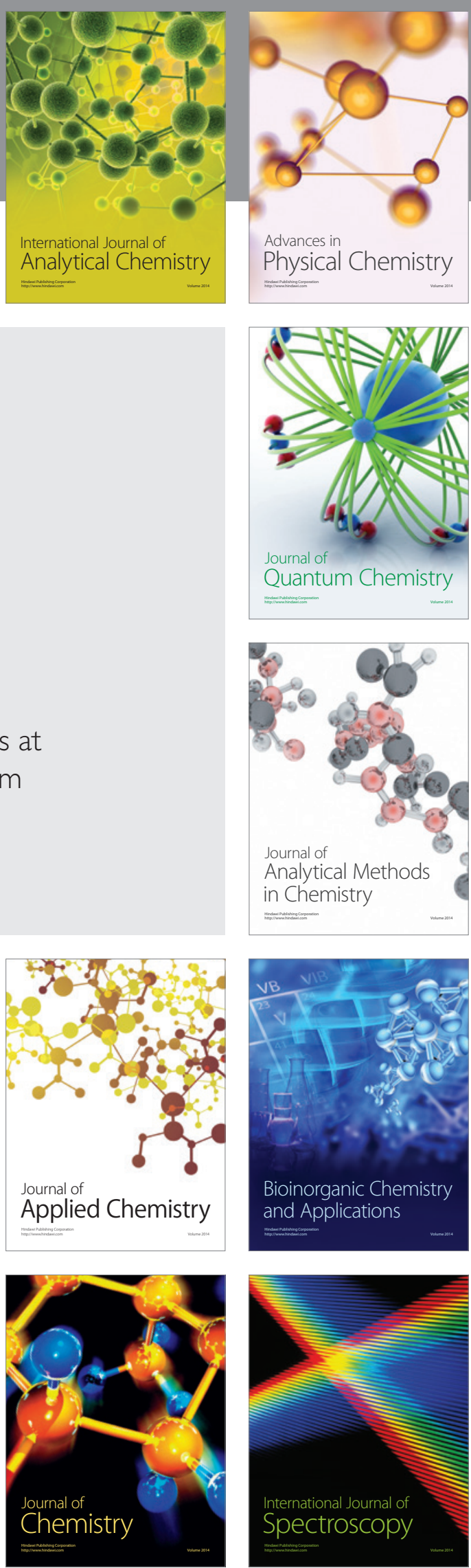